\title{
Stories of courage in a group of asylum seekers for an inclusive and sustainable future
}

\author{
Sara Santilli ${ }^{1}$ (D ) Ilaria Di Maggio ${ }^{1}$ Maria Cristina Ginevra ${ }^{1} \cdot$ Laura Nota $^{1}$ • \\ Salvatore Soresi ${ }^{1}$
}

Received: 18 November 2019 / Accepted: 9 September 2021 / Published online: 30 September 2021

(c) The Author(s) 2021

\begin{abstract}
Asylum seekers experience conditions of social disadvantage, poor labor market outcomes, and low-paid jobs. Therefore, vocational guidance and career counseling must function as a supportive social practice for asylum seekers giving voice to them and focusing on their strengths, such as courage. The present study examined the personal stories of courage of 71 asylum seekers who migrated to Italy. Results highlight situations characterized by undignified living conditions, dehumanizing transitions, and barriers imposed on future aspirations. These voices could become a significant starting point to consider asylum seekers' future in the perspective of an inclusive and sustainable future.
\end{abstract}

Keywords Vocational guidance $\cdot$ Courage $\cdot$ Asylum seekers

\section{Résumé}

Histoires de courage dans un groupe de demandeur-se-s d'asile pour un avenir inclusif et durable Les demandeur-se-s d'asile font face à des conditions de désavantage social, des résultats médiocres sur le marché du travail et des emplois mal rémunérés. Par conséquent, l'orientation scolaire et professionnelle doit fonctionner comme une pratique sociale de soutien pour les demandeur-se-s d'asile en leur don-

Sara Santilli

santilli.sara@gmail.com; sara.santilli@unipd.it

Ilaria Di Maggio

ilaria.dimaggio@unipd.it

Maria Cristina Ginevra

mariacristina.ginevra@unipd.it

Laura Nota

laura.nota@unipd.it

Salvatore Soresi

salavatore.soresi@unipd.it

1 Department of Philosophy, Sociology, Education, and Applied Psychology, University of Padova, via Venezia, 14, 35131 Padua, Italy 
nant la parole et en se concentrant sur leurs forces, comme le courage. La présente étude a examiné les histoires personnelles de courage de 71 demandeur-se-s d'asile qui ont migré en Italie. Les résultats mettent en évidence des situations caractérisées par des conditions de vie indignes, des transitions déshumanisantes et des obstacles imposés aux aspirations futures. Ces voix pourraient devenir un point de départ important pour envisager l'avenir des demandeur-se-s d'asile dans la perspective d'un avenir inclusif et durable.

\section{Zusammenfassung}

Geschichten des Mutes in einer Gruppe von Asylbewerbern für eine inklusive und nachhaltige Zukunft Asylbewerber sind von sozialer Benachteiligung, wenig Arbeitsmarkterfolg und schlecht bezahlten Jobs betroffen. Daher muss die Berufsund Laufbahnberatung als unterstützende soziale Praxis für Asylsuchende fungieren, indem sie ihnen eine Stimme gibt und sich auf ihre Stärken, wie zum Beispiel Mut, konzentriert. Die vorliegende Studie untersuchte die persönlichen Geschichten von Mut von 71 Asylbewerbern, die nach Italien migriert sind. Die Ergebnisse heben Situationen hervor, die durch unwürdige Lebensbedingungen, entmenschlichende Übergänge und Barrieren für zukünftige Bestrebungen gekennzeichnet sind. Diese Stimmen könnten zu einem wichtigen Ausgangspunkt werden, um die Zukunft der Asylsuchenden in der Perspektive einer inklusiven und nachhaltigen Zukunft zu betrachten.

\section{Resumen}

Historias de coraje en un grupo de solicitantes de asilo para un futuro inclusivo y sostenible Los solicitantes de asilo experimentan condiciones de desventaja social, malos resultados en el mercado laboral y empleos mal pagados. Por lo tanto, la orientación profesional y el asesoramiento sobre la carrera deben funcionar como una práctica social de apoyo para los solicitantes de asilo, dándoles voz y centrándose en sus puntos fuertes, como la valentía. El presente estudio examinó las historias personales de coraje de 71 solicitantes de asilo que emigraron a Italia. Los resultados ponen de manifiesto situaciones caracterizadas por condiciones de vida indignas, transiciones deshumanizadas y barreras impuestas a las aspiraciones futuras. Estas voces podrían convertirse en un importante punto de partida para considerar el futuro de los solicitantes de asilo en la perspectiva de un futuro inclusivo y sostenible.

\section{Introduction}

Nowadays, politics and the development of the economy and society are contributing to the creation of challenging situations for people, especially if vulnerable (Hardoon \& Slater, 2015). Poverty, social conflicts, disasters, human rights violations: all these aspects represent a collection of the so-called push factors that tend to encourage more and more people to escape from their homeland, risking their lives to reach a different country. "Push factors" involve the advantageous conditions that encourage people to move to different countries and change their life projects. 
These factors include political stability, wellbeing, better services, and respect for human life (Baudassé et al., 2018; Parkins, 2010).

Migration appears as a complex phenomenon related to neoliberal globalization. Globalization allowed people from the most impoverished regions to find out the characteristics of the wealthiest countries, and to desire goods, products (Crouch, 2018). All this has led to what Ong called, in 2004, the capitalization of citizenship. According to this concept, migrants' right to international circulation is granted or refused based on their wealth or their economic/social status, and so on. Starting from his studies regarding the recent Chinese migrations towards the USA and Canada, Aihwa Ong (2004) described the process of citizenship hierarchization as the emergence of a "selective cosmopolitism." His research confirms the idea that a "world without borders" characterized by "freedom of movement" is not part of the political and economic agenda.

As reported by Düvell (2004), the process of citizenship hierarchization stresses the differences among different individuals, not to underline their value in a perspective of social progress, but because of ideological derivations. The distinction between genders, races, and nations reflects the division of work, the fragmentation of job markets, and the life conditions people experience (Mulvey \& Davidson, 2019). Migration policies are oriented towards maintaining, controlling, and managing borders, introducing different schemes to control people's movements.

While neoliberal globalization has promoted the free movement of capital, goods, and skilled labor, it has also strongly penalized unskilled workers' movement, particularly along the South-North axis. It emerges that the "freedom of movement" exists just for global élites, highly qualified professionals, and wealthy tourists. Job movements undergo heavy regulation, and poor people with stories of migration cannot move at all (Joseph \& Leach, 2016). Crawley and Duvell (2017) highlighted two distinct migration routes into Europe. One is related to an Eastern Mediterranean route that originates primarily in Central Asian, Middle Eastern, and North African States transiting through Turkey and arriving in Greece. The other one is a Central Mediterranean route that mainly originates from the African States transiting through Libya and arriving in Malta and Italy. As evidence of this, Koddenbrock (2019) underlines, for example, that, in Sub-saharan Africa, the degree of emigration towards OECD countries in 1990 and 2000 was, respectively, of .3\% and .4\% for unskilled workers and $13.2 \%$ and $12,8 \%$ for highly qualified workers.

In line with this premise, those who do not belong to favoured groups such as highly qualified workers have to face massive challenges that could jeopardize their life. In 2018, according to the data published by UNCHR, more or less 70.8 million people worldwide were forced to flee their country. European countries are among the most chosen nations by asylum seekers, with 200.000 people per year. Asylum seekers are people who achieved an international protection status and entered a host country to seek protection while waiting for preparation, submission, or adjudication. Germany, Hungary, Sweden, Austria, and Italy are the European countries with the highest number of asylum requests (UNHCR, 2019). For the Italian government, asylum seekers are foreigners who made a formal request for protection and hospitality based on international agreements. These people are seeking asylum because, in their homeland, they are persecuted for different reasons: for their 
political opinions, their belonging to a religious group or a specific social class, their ethnicity, and so on. The reason why they flee their country could also be related to the fact that the place where they used to live became a completely unsafe warzone. Since the asylum application has to be submitted in the land where the person is seeking asylum and since the Italian and European law does not include a specific way to enter a country for those who would like to apply for asylum, migrants travel mostly illegally, landing on Italian shores.

These movements are journeys of hope, full of difficulties and dangers, both for people's physical and psychological health (Press, 2017). As denounced by Amnesty International (2019 https://www.amnesty.it/giornata-mondiale-rifugiatostrage-mediterraneo/), the number of migrations seems lower today than in 2017. In particular, regarding the route that involves the crossing of the Mediterranean sea, deaths at sea seem to be raised in 2018 and 2019 compared to those recorded in 2017 because of ineffective national and European policies. The data released by UNHCR estimated until now, 637 deaths at sea in the crossing Libya-Italy; 1041 deaths in the Mediterranean.

Press (2017) underlines that the journeys involve many different challenges and difficult situations: changing routes, constant recalculations, and fast decisions that can make the difference between life and death. Besides, people may be captured during their journey or bought and sold by human traffickers. Press (2017) also showed that journeys could be considered quests to stay alive. Asylum seekers are dealing with and overcoming massive human rights abuses on a scale not yet generally recognized by Western society. Though photos of overladen rafts and ships that lead to drownings appear through the media, much less is known about the tortures, beatings, rapes, and selling and buying of human beings that the travellers suffer in the majority of the cases.

If the crossings are successful, people have to face other severe conditions associated with the challenges that threaten the basic needs for survival and belonging (Schultheiss et al., 2011), having weak legal and socio-economic positions (Marfleet, 2006; O’Neill, 2009, 2010).

In their destination countries, asylum seekers do not know the environment around them and it is difficult for them to take advantage of their skills, qualifications, and experiences. These experiences leave people that decide to stay and request asylum unprepared to express the full extent of their knowledge and education and make it harder for them to contribute to the local or national economy with their full potential (Joseph \& Leach, 2016). Therefore, unemployment and underemployment become dominant themes in their lives since they are required to fit into pre-existing systems and procedures with which they are unfamiliar. Prejudices and negative attitudes further undermine skills and self-efficacy resulting in hidden and unrecognized talents and disruptions in identity. As a result, asylum seekers' position becomes the defining feature for many individuals (Mulvey \& Davidson, 2019).

Press's study (2017) provides additional insight into the personality of migrants that decide to live in the host country and request asylum. He stated that they are characterized by the courage to cope with and survive not only commercial exploitation but also the severe abuse of their human rights. The precarious conditions experienced by asylum seekers are related to many factors. These factors include 
delays in processing applications, obstacles to employment, racial discrimination, loneliness, difficulties in locating the service due to social problems, isolation, poor knowledge of the organization of the services and their rights, inadequate understanding of the language and being confronted with exploitative working conditions and hostile state apparatuses (Aragona et al., 2012; Berriane \& De Haas, 2012).

\section{Vocational guidance, career counseling, and migration}

Career guidance and career counseling must help asylum seekers to detect the best strategies to face these challenges both individually and collectively. Counselors could explore different response strategies to these challenges that could be carried out together with citizens so that professional guidance could serve as an amplifier of personal reflections of groups of people with vulnerabilities. These different response strategies could also help in the collection of socially acquired knowledge (Hooley et al., 2020). All of this translates into encouraging people to think about the policies related to the situation they are living in and to consider their position on the approaches that governments take. This process can help people with vulnerabilities to see injustice and iniquity and, at the same time, create alliances so that they can be guaranteed a decent future and job. Career guidance and career counseling must bring up these topics on a social level, promote people-friendly policies, and build solidarity (Hooley et al., 2018; Soresi, 2018). It is necessary to encourage people to aspire and build better futures for everyone, in the awareness of the threats and challenges that we have to face. In line with this, career guidance activities should support individuals and groups to consider and reconsider work, hobbies, and training in the light of new information and experiences, to take both individual and collective action through activities aimed at developing critical consciousness, and to support people to work together (Hooley et al., 2020).

This paper stems from the reflections made in the sphere of the Life Design approach (Nota \& Rossier, 2015; Santilli et al., 2019; Savickas et al., 2009). The latter highlighted the idea that future building is a complex process, which is also the result of the experienced contextual conditions. In supporting this construction, it is necessary to abandon reductionist and linear views focused on person-environment matching, invest in more inclusive and sustainable visions of the future and engage in advocacy activities. Besides, attention and value have been recently given to the inclusive and sustainable connotations that this process is supposed to have, with particular emphasis on social and ethical values, with specific attention on people with vulnerabilities (such as asylum seekers), caring for them and paying attention to their life contexts. Therefore, it is crucial to give voice to people, to bring out the adverse conditions they experienced, through advocacy actions in order to help them and the extended society to spread the knowledge needed to recognize discrimination, barriers, exploitation, and act to overcome them to consider trajectories that promote future models focused on inclusion and sustainability (Guichard, \& Pouyaud, 2018; Nota, \& Soresi, 2018). 
All this is in relation to the 2030 Agenda for Sustainable Development approved in September 2015 by 193 United Nations members who translated the main future priorities into 17 important goals to pursue with everybody's commitment. It developed an action plan expanding the intervening contexts, that is to say, all the fields and actions that concern organizations, systems, policies, and social practices, that can be modified in order to pursue the goal of building a sustainable world from an environmental, economic, and social point of view (Scuttari \& Nota, 2019). When asking everyone to do their part in order to build a future of quality, as recently supported by Giovannini (2018) "the crucial question that we have to answer concerns the kind of future that we would like to build in order to counter present and future worries" (p. 97). In career counseling and vocational designing, there is the need to encourage activities aimed at overcoming the idea that the individual is the only responsible and architect of its future. It is also important to stimulate the reconsideration of structural factors which can promote equity, trust, cooperation, justice, and fairness, the heart of social sustainability (Roca-Puig, 2019). In this view, it is important to support people to make the barriers public, work together to face the current adverse conditions, and promote positive resources to cope with these undesirable situations to design a sustainable future (Ginevra et al., 2018; Madžarević et al., 2016). It is also fundamental to realize actions that right a wrong and bring about a fairer society (Hooley et al., 2018; Santilli et al., in press.).

In order to move towards this direction, with this study, we would like to start from courage, and specifically from Putman $(2010,2014)$ definition of it. He considered courage as a resource to bring out the adverse conditions experienced by asylum seekers and their efforts to face them. More specifically, with this contribution, we would like to give voice to asylum seekers, providing a safe space for people with disadvantages who are often powerless, so that they can be heard. This process starts from the analysis of courageous behaviours that asylum seekers exhibited during their transition to Italy. Moreover, we would like to underline the strategies they have used to address the fears related to the strenuous transit route, to support them in developing orientation toward the future (Margherita \& Tessitore, 2019). Courage, as underlined by Press (2011), is an element that motivates people to seek living conditions based on human rights and democracy. At the same time, Apples et al. (2020) highlight how people perceived as courageous can promote individual socio-political participation. This is considered by the authors as a fundamental ingredient for the construction of democratic contexts.

\section{Definition and types of courage}

Putman (2010) defined courage as the first human virtue that, at the same time, makes all of the other virtues possible. In line with this, courage is considered by Peterson and Seligman (2004), a combination of strengths that include bravery, integrity, persistence, and vitality. It promotes "the exercise of will to accomplish goals in the face of opposition, either external or internal" (Peterson \& Seligman, 2004, p. 199). Moreover, Putman $(2004,2010)$ underlined that courage is essential in dealing with obstacles, worries, and challenges that people with vulnerabilities 
have to face. It represents the ability to act for a meaningful (good, noble, or practical) cause, despite experiencing the fear associated with the perception of a threat, exceeding the available resources (Woodard, 2004).

In literature, there are numerous references to the definition of "bad courage". These consider the pursuit of a goal as something that the society in which one lives does not perceive as noble (Puty et al., 2015). An example of this is represented by particularly atrocious acts, such as the ones perpetrated by terrorists, and selfdirected ones, such as suicide. A courageous action can be labeled as "bad courage" for one of two reasons: the motivation of the actor is seen as something unwanted by society, or the action that is being carried out is seen as something unacceptable. To better define what makes a courageous action, it is useful to consider the motivation behind the goal and also the goal itself. In this work, we refer to the vision of courage as a virtue.

Pury et al. (2014) suggest differentiating between different types of "good" courage, considering the dangerous situations in which courage is used and the goals that it allows to achieve. Based on this, it is possible to identify three types of courage: physical courage, moral courage, and psychological courage. Physical courage is about being involved voluntarily in physically dangerous situations, characterized by high physical risks and the achievement of noble goals related to protecting oneself and others. Moral courage consists in standing up to the powerful ones for what one believes in, with the risk that others will treat them wrong. High risks in the social context characterize it. Moral courage involves entering voluntarily into a morally and socially dangerous situation and achieving noble goals related to personal, moral, and ethical values. Psychological courage is about facing unpleasant truths or unpleasant life experiences to reach wellness. Psychological courage is characterized by high emotional and psychological risks connected to high internal benefits. More specifically, risks dealing with psychological courage are related to the loss of psychological stability for personal growth (Putman, 2004, 2010). In other words, psychological courage involves entering voluntarily into emotional and psychologically dangerous situations to achieve wellness and personal growth.

\section{Stories of courage}

Many different authors focused their attention on courageous life narrations, to better understand both the contextual and personal barriers that people experience, but also to be able to analyse the coping strategies used by the people involved (Clancy et al., 2015; Di Maggio et al., 2019; Santilli et al., in press; Tasker, 2002). For example, Clancy et al. (2015), by analysing the narrations of older people living in residential care, showed as their stories of courage provided specific knowledge about the individuals and the environment they lived in. Moreover, this study showed the importance of narrating stories regarding courageous actions performed by older people, because in this way, it can help safeguard their integrity and promote their wellbeing. Similar results have been shown by Di Maggio (2019), Santilli et al., (in press): involving people with vulnerabilities (people with substance use disorders 
and precarious young workers) showed that analysing stories of courage can be useful in order to analyse the contexts in which vulnerability takes shape.

Moreover, stories of courage also allowed us to analyse specific types of courage (physical, psychological, and moral courage), that people implement to face them. These types of courage seem to be strictly connected to the contextual barriers experienced by people with vulnerabilities (Di Maggio et al., 2019; Santilli et al., in press). Moreover, other studies by Di Maggio (2019), Santilli et al. (in press) in line with the studies of Clancy et al. (2015), show how stressing courage and giving the possibility to tell one's personal stories of courage can represent an essential resource in order to give back to people with vulnerabilities their dignity. Telling a story of courage could be the start of a process that leads to a deeper understanding of one's consciousness, to reduce the perceived weight of individual responsibilities, to develop strategies to let people hear, from a professional point of view, the voice of these individuals and to encourage forms of reconsideration of their working and social conditions (Di Maggio et al., 2019; Santilli et al., in press). Considering the literature related to trauma testimony (Andrews, 2010) and the study by Pury et al. (2007), telling stories of courage could help individuals open themselves up to the other characters in their stories. Thereby, it is possible, for the individuals involved, to see that they are not alone and to positively promote their vision of the future within challenging contexts.

In this regard, authors such as Brachet (2016), Press (2017), Schapendonk and Steel (2014) analyzed the journey and the challenges connected to it and concluded that courage can be described as a useful resource to survive and to be able to face challenges, giving back dignity to people with stories of migration. Furthermore, the results of these studies showed a portrait of people with stories of migration sharply in contrast with the typical public portrayal of them as weak and helpless survivors of the sea crossing or as criminals. It is important to promote a more accurate portrait of asylum seekers, based on the knowledge of the profound and transformative impacts of migration and of the (re-)construction of identities and the social/political context where migration takes shape. This portrait can help to better inform policymakers, who can shape reception and settlement policies in host countries that are more responsive to the transitional (or transit) experience (Benezer \& Zetter, 2014).

\section{Research goal}

This research analyses the stories of courage told by a group of asylum seekers that found shelter in Italy. Our research considers the relevance of a better understanding of the migration phenomenon and its various challenges. Using the same method used by Santilli et al. (in press) and Di Maggio et al. (2019), the themes underlying the narration and the types of courage used by people with migration stories have been analysed. As regards the themes, in line with the study by Santilli et al. (in press), we hypothesized that the narrations regarding courage told by people with stories of migration could provide an account of the social, political, and cultural barriers to be faced with courage. These barriers are related to their home country, their journey, and their host country. As far as the different types of courage are 
concerned, considering the low number of studies that analysed courage in people with stories of migration, the aim was to explore this aspect, hypothesizing that, since they faced many different challenges, they had to employ both physical, psychological, and moral courage.

\section{Method}

\section{Participants}

The sample included 71 asylum seekers, sixty-nine of which men (97.2\%) and two women $(2.8 \%)$. On average, participants were 23.51 years old $(S D=3.12)$. Of the sixty-nine men, two were not included due to language difficulties. On the other hand, both of the women joined the activity. Participants stated, on average, to have been in Italy for more or less one year $(M=11.39$ months; $S D=1.21)$. As regards the level of education, participants stated, on average, to have 15 years of education $(S D=2.02)$.

\section{Courage interview}

Considering the study by Pury et al. (2007), a semi-structured interview was developed. The interview was presented to participants as follows: "The purpose of the present interview is to better understand the experiences of courage that people live. Life is often complex and difficult. For this reason, it requires patience, perseverance, and courage. In your experience, have you ever been courageous? If yes, try to describe a situation in which you were a courageous person". Before the interview, an opening phase introduced the activity in order to create trust between the interviewee and the interviewer. Then, participants were called to describe a life event that they had courageously faced, describing where the event occurred, who else was involved, how they felt, what they thought, what the consequences were, and how other people behaved in that situation.

\section{Procedure}

Specifically, participants were identified by contacting reception canters for asylum seekers for a career design project aimed at stimulating people with stories of migration to reflect on the future, also considering their courageous experiences. A snowball sampling procedure was used to recruit the volunteers that participated in a semi-structured interview (Morrow, 2005; Thomas, \& Antony, 2017). The participants were then contacted by a career counselor, who explained the project aim and communicated to them that the collected information would be protected by professional confidentiality, following ethical procedures ruled out by the Italian Ethical Principles of Psychologists. The interview took approximately $30 \mathrm{~min}$ to complete. Interviews were audiotaped, transcribed verbatim, and examined by the interviewers for accuracy. At the beginning of the interview, a brief introduction of 
the interviewee and the interviewer was designed to build a connection among each participant. People told their training and past work experiences, fostering forms of reflection on what they have experienced. At the end of the activities, all participants received personalized feedback including the analysis of the courageous actions that have allowed them to overcome the barriers. This activity also emphasized participants' strengths with the idea of starting forms of support with professionals to stimulate the generalization process aimed at activating strategies for managing contextual situations that may represent barriers to human life and its development as well as future planning. We also informed participants that, with this study, through their voices, we would have promoted a public, scientific, and community debate on the structural aspects that society may develop to reduce negative impacts and generate equity, justice, and inclusion (Diemer et al., 2016).

\section{Data analysis}

A thematic analysis was used to identify the themes and types of courage that emerged in the interview (Fereday \& Muir-Cochrane, 2006; Miller \& Shifflet, 2016). This analysis employs a qualitative method aimed at identifying, reporting, and examining data for the meanings produced in and by people, situations, and events (Braun \& Clarke, 2006; Riessman, 2008). Specifically, a hybrid approach regarding the method of thematic analysis was chosen for this study (Fereday \& Muir-Cochrane, 2006; Miller \& Shifflet, 2016). Following this method, deductive and inductive codes were generated by two independent researchers. Thanks to the top-down, deductive, theoretical process, we produced a set of a priori (or preempirical) codes that came from the research aims and the questions asked in the interviews. A bottom-up, inductive, data-driven process was used and resulted in a series of a posteriori (post-empirical) codes derived from an examination of generated data (Swain, 2018). Inductive codes were produced to understand the themes of the stories regarding courage, related to participants' life events. During the inductive process, the first and the second authors coded the transcripts following the procedure of Braun and Clarke (2006), which includes: (1) familiarization with data, (2) coding, (3) searching for themes, (4) reviewing themes, (5) defining and naming themes, and 6) writing up. The first and second authors worked independently. They examined all the answers to the interview, coded, and searched for themes. The percentage of agreement between the two coders was over $95 \%$ for all codes. Then, the researchers worked together on revisiting, defining, and naming themes.

At the same time, deductive codes were produced to understand the type of courage related to participants' stories based on the suggestion of Pury et al. (2014) and Rate et al. (2007). Specifically, we classified participants' answers as physical courage when the courageous behavior regarded physically dangerous events and the achievement of noble goals related to protecting themselves and others. We detected moral courage when participants' courageous behaviors regarded morally and/or socially dangerous events and the achievement of noble goals related to moral and ethical personal values. We classified psychological courage when the courageous 
behaviors regarded emotionally and/or psychologically dangerous events and the achievement of noble goals related to wellness and personal growth.

Several writing samples (Boyatzis, 1998) were applied to determine the applicability and reliability of the codes generated. The range of Cohen's Kappa inter-rater reliability index obtained was .85-.91. In the case of divergence in the classification, researchers met and tried to reach a consensus. Once the codes were revised to reflect the data set, they were applied to the full sample (Miller \& Shifflet, 2016).

\section{Results}

First, the themes underlying the stories of courage were examined. After this, the types of courage (physical, moral, and psychological courage) have been divided and analysed.

\section{Themes underlying stories of courage}

Stories of courage are addressed with a description of the emerged themes (classification units) and with quotes of categories. Table 1 presents an overview of all the themes and categories. More specifically, as regards the themes, three classification units were identified: stories related to experiences before the migration journey, stories related to the migration journey, and stories related to life experiences after the migration journey.

\section{Stories related to life experiences before the migration journey}

Thirty-five participants (49.3\%) reported stories of courage related to life experiences before the migration journey. More specifically, as reported in Table 1, $22.63 \%$ of these participants reported to have been courageous during life experiences related to the violation of human rights, such as the right to personal freedom (e.g. "To say what you think in the Gambia you need a lot of courage"; "In Libya, police attacks fiercely... you can't do or say anything"; "when I was a child, I went

Table 1 Frequencies and percentages of courage stories themes and categories

\begin{tabular}{llrr}
\hline Themes of courage stories & & $\%$ & $F$ \\
\hline Stories related to life experiences before migration journey & Violation of human rights & 62.9 & 22 \\
$(49.3 \%)$ & Fears for uncertainties future & 37.1 & 13 \\
Stories related to migration journey & Indecent life conditions & 61.9 & 13 \\
$(29.6 \%)$ & Help and cooperation & 19.05 & 4 \\
& Fears for uncertainties future & 19.05 & 4 \\
Stories related to life experiences after migration journey & Fears for future aspirations & 53.3 & 8 \\
$(21.1 \%)$ & Indecent work condition & 26.7 & 4 \\
& Traumatic experiences & 20 & 3 \\
\hline
\end{tabular}


through very dangerous places and lived my life afraid to die"), the right to life and to live in dignity (e.g. "my family and I used to live in extreme poverty and my mother told me to leave because we couldn't survive in that way anymore"; "We didn't have food to feed us all, so I left to find a better life and to give my family what they needed"; "my family was poor, I used to look after my little brother who was sick and hungry"). $37.1 \%$ of participants reported, on the other hand, stories of courage connected to having to face fears and future uncertainties such as those linked to the journey (e.g. "when I had to decide to take this long journey I had $50 \%$ chances of living and 50\% of dying"; "the sea journey was the hardest thing, it takes much more than courage. You are afraid, lonely, anxious, and you do not know if you will be safe"), linked to their relatives (e.g. "Saying goodbye to my family and not knowing if I would have ever seen them again has been really difficult..."; "when my mother told me to run away, I ran away alone, without being able to say goodbye to my family... It was terrible and I was full of fear"; "I had the courage to give up everything, my family and my belongings to leave and save myself") and also linked to their own life away from home in their host country (e.g., "I had the courage to come to Italy. For me, it was a challenge since I didn't know what to expect and I didn't know the Italian language"; "I was afraid. To survive I had to be brave when I had to cross the borders to get to Italy; I didn't know what would happen to me").

\section{Stories related to the migration journey}

Twenty-one participants (29.6\%) reported stories of courage related to the migration journey. More specifically, as reported in Table 1, 61.9\% of participants reported having been courageous in experiences related to indecent life conditions that jeopardized their right to life (e.g., "At sea, I was hurt because we all were too close to each other. During a moment of panic, some of the other people got up and pushed me..."; "When I was at sea I was hungry, thirsty, it was hot and I was alone... I thought I would have died"). A percentage of $19 \%$ reported having been courageous in helping and cooperating with others (e.g., "When I was on the boat, I saw some people falling, I couldn't swim well, so I tried my best to help them and we managed to save them"). Finally, $19.5 \%$ of participants reported having been courageous in facing fears and future uncertainties (e.g., "When I had to face a long journey by sea without knowing what would have happened to me, I was constantly anxious"; "When you are at sea for so many hours, not knowing if you will survive, you grab onto hope and courage...").

\section{Stories related to life experiences after the migration journey}

Fifteen participants $(21.1 \%)$ reported courage stories related to life experiences after the migration journey. More specifically, as reported in Table 1, 53.3\% of participants reported having been courageous to face fears and uncertainties connected to the ability to realize future aspirations (e.g., "I'm studying Italian and I'm trying to prepare my life because, for now, I'm not prepared to have a proper life, I want to have my documents and to find a job"; "In Somalia, there has been a war for 
27 years. Since I was young, I have always had the courage and I would like to have strength and courage, now that I am here, to find the way to do something important for me and my family and to be able to bring peace to my country"). $26.7 \%$ of participants reported having been courageous to face inappropriate working condition requests (e.g., "When I had to go to work off the books in the fields"; "When I had to do job interviews even if I was depreciated because I couldn't speak Italian well"). Finally, 20\% of participants reported having been courageous to face fears connected to traumatic experiences (e.g. "I need the courage to sleep at night because I think about all the people I've seen suffering and dying and it seems to relive these experiences every night"; "My head is full of thoughts, mostly at night. When I lay down in bed, they get darker and I have to be courageous to sleep and wake up again in the morning").

\section{Types of courage}

As reported in Table 2, physical courage is reported in $43.7 \%$ of the stories. In these stories, participants used courage mainly to face physical dangerous situations and the achievement of noble goals related to protecting themselves and others (e.g., "When I was at sea I had courage because I was afraid to die"; "At sea, I thought that nobody would have come to rescue us and the fear of death still haunts me"). Moral courage is mentioned in $4.2 \%$ of the stories. In these stories, participants used courage mainly to face morally and socially dangerous situations and the achievement of noble goals related to personal, moral, and ethical values (e.g., "My brother has been beaten many times by my uncles and I had the courage to defend him. For this reason, we escaped"; "When I had a fight with my boss because he hit my mother"). Finally, $52.1 \%$ of the stories referred to psychological courage. In these stories, participants used courage mainly to face emotional and psychological dangerous situations and the achievement of noble goals related to wellness and personal growth ("Saying goodbye to my family and knowing that I will never see them again"; "I was courageous to come to Italy... because here I am alone").

\section{Discussion}

The present study aims at giving voice to asylum seekers through their stories of courage to understand this phenomenon and its complexity in Italy as a host country. Specifically, we analysed stories of courage regarding migration in terms of themes and types using a qualitative methodology.

Table 2 Frequencies and percentages of different types of courage

\begin{tabular}{lcr}
\hline Different types of courage & $\%$ & $F$ \\
\hline Physical courage & 43.7 & 31 \\
Moral courage & 52.1 & 37 \\
Psychological courage & 4.2 & 3 \\
\hline
\end{tabular}


The analyses carried out have revealed that stories of courage involve three main themes. The first theme is related to life experiences in the native country, related to undignified living conditions permeated by the continuing violation of human rights. These results are in line with various studies that analysed the migration phenomenon in terms of push and pull factors. The outcome of this research underlines the idea that some people, living in miserable conditions, challenged heavily at both physical and psychological levels, decide to undertake a migration journey to find more dignified living conditions, without any certainty of success (Parkins, 2010; Vogt, 2013).

The second theme is related to life experiences during the migration journey. The stories highlight the courage to face situations capable, even today, of putting their survival at risk (Press, 2017). The stories presented revealed the presence of collaboration between "travellers" to help each other, while focused on how to stay alive. These results support what has already been reported by other colleagues about these trips and the efforts that people are making to face inhuman conditions on the doorstep of countries that paradoxically value democratic visions focused on human rights (Press, 2017; Schapendonk \& Steel, 2014).

The third theme is related to experiences lived after the migration journey. These stories refer to the courage in managing the traumas suffered that seem to recur in an intrusive way in the lives of the people with a story of migration. It also involves facing fears and uncertainties related to being able to realize dreams and ideas about the future and facing undignified working conditions. The presence of stories related to emotional trauma control, a common condition in people with stories of migration exposed to stressful situations over a prolonged period (Thompson et al., 2018), can be explained based on Putman's considerations (2010). Putman states that dealing with unpleasant memories and emotionally charged experiences requires courage, especially psychological courage since such memories can put a strain on the psychological stability of the person. The narrations of people with a story of migration involve courage as a resource to face anxieties and fears related to not being able to learn and develop new skills or to realize the dreams that led them to face the experience of migration. These stories confirm the work barriers reported in the IX Annual Report of the Directorate General for Migration and Integration Policies (2019) and various studies (e.g., Bimrose \& McNair, 2011; Santilli et al., in press.) on undignified working conditions of asylum seekers (i.e., lower wages, more accidents, undeclared work, job insecurity, low-skilled jobs, etc.). In this situation, in our opinion, people find themselves living with conditions that bring them back, after their journey, to undignified living standards, despite the principles and values of reference applied in these new environments.

In the presence of such conditions, the types of courage that seem to be most frequently employed are those related to physical and psychological courage. Moral courage is less frequent than the other types of courage. These results highlighted how people that are busy managing their survival (e.g., the violation of the most elementary human rights, anxieties, fears, undignified demands) need physical and psychological courage and have little mental space to shift attention to severe conditions experienced by others. We believe, alongside Chapa and Stringer (2013), that, 
to act with moral courage, it is necessary to be able to experience life situations that are not anchored only to survival.

Overall, the results suggest that asylum seekers experience challenges, difficulties, and barriers that undermine their integrity and physical and psychological wellbeing for a very long time, before embarking on the journey, during the migration journey, and even upon arrival in the host country, which can put a strain on them. In this globalized world that allows access to information on these journeys of hope, these people probably find themselves thinking and reflecting on what they are facing. Thus, even if they cannot imagine the set of brutalities they encounter, they may think about at least some of the barriers, how people can face them, and the fact that they have to 'gather' all their courage to face these challenges. This leads us to imagine that probably the people who start the journey are the most courageous and that they have the most substantial psychological resources, as well as the necessary money, to be able to cope with these many difficulties (Bono, 2018). These reflections could help to understand why those who undertake the journey are still a minority and also, and above all, how the barriers that have emerged here, to be managed one after the other without a sort of psychological break, are the result of deliberate choices in Western countries to build 'natural deterrents' to the migration phenomenon.

The stories of courage also reveal the presence of a process based not only on the obscuring of the factors that underlie migration processes but also on the presence of barriers that make people increasingly fragile, probably to facilitate forms of exploitation and the maintenance of a paternalistic vision of the people who support the demand for services which often represent sources of profit and income. This is in line with what has been argued by Page (2014), who has pointed out that 'ethical capitalism' is the typical consumer-capitalist response to relations of exploitation. As suggested by Howard and Forin (2019), the pity- and counter-hegemonic politics are limited. So the pity should be replaced by outrage and shame by the structural critique of our society. Professionals and policymakers are undoubtedly right to draw attention to asylum seekers' injustices. However, this has to be done systematically by analysing the whole system. The specific injustice is merely an expression of the Italian migration regime, its border policies, and neoliberal politics.

\section{Limitations and directions for future studies}

While we believe that our design guidelines constitute an essential foundation for giving voice to asylum seekers, we must acknowledge that the categories and results may not apply to all contexts. Specifically, it is worth pointing out that we contextualized the interviews in the North of Italy's application area. Hence, further research is needed to understand how the guidelines can be applied in other contexts. Considering the gender discrepancy in our study, since " $73 \%$ of the 1.2 million asylum seekers in Europe are men" (Giagrande. 2016, p. 109), future studies should consider and analyse the role of gender variables on stories of courage in asylum seekers. Future studies could be useful to accompany the use of narrative tools with selfreport instruments and direct observation of the contexts and variables considered in 
this study. Besides, to use qualitative procedures, Shumam and Bohmer (2004) suggest that it is important to consider that asylum seeker have a radically different narrative system from the one existing in Western countries. Many asylum seekers who have lived traumatic experiences share their stories only through poor narratives that rarely depict their traumas in exact terms. According to the authors, victims do not describe the trauma at all, especially in the initial phase. The description of the event is mostly generic. This can be connected to the cultural differences with the narration modality of traumatic experiences.

Finally, as Hooley et al. (2018) suggested, it would be worthwhile to study this topic with a broader vision in future research, considering the problem at two levels: local and global.

\section{Theoretical and practical implications}

The findings of this study have both theoretical and practical implications. In terms of theoretical implications, the results of this research confirmed the importance of examining the themes that emerge from the narrative of asylum seekers not only to investigate the migration phenomena more deeply but also to give voice to the injustice and discrimination they experience (Di Maggio et al., 2019; Hooley et al., 2018). Furthermore, the study suggested that narratives, specifically the stories of courage, are deeply contextually embedded and represent a recursive interaction between people and the contextual conditions in which they live in both their home and host countries (McMahon et al., 2012). These results emphasize the need to proceed with in-depth reflections on the role of the context within the Life Design approach, as well as the necessity to care about an inclusive and sustainable vision of the future. The context we are considering is structured around processes of vulnerability which are also the result of the neoliberal policies we have mentioned and which, to be modified, requires attention from vocational guidance professionals so that they can be promoters of change and transformation both for people and for the contexts themselves (Nota et al., in press.).

In terms of practical implications, this study demonstrated the importance of assisting asylum seekers in giving voice to dehumanized and undignified human and work conditions and how people who experienced them successfully handled them. Professionals can use these stories of courage to allow an individual analysis not only regarding the demanding situations experienced but also about the contextual barriers that affect their stories concerning the broad socio-political systems of the origin and the host country. This can allow a more in-depth knowledge of the migratory phenomenon and reduce the processes of culpability. In turn, the analysis of stories of courage can allow the emergence of the person's resources and their agent role in facing numerous challenges. This can help people create a positive vision of themselves, increase their levels of self-esteem (Toporek \& Cohen, 2017), and contribute to spreading a more positive image of asylum seekers in the host country. These results suggest, as also supported by Obschonka and Hahn (2018), that activities aimed at highlighting individual resources help people to see "possibilities" in their context despite the challenges they face in the short term, generating, through 
a motivational process, a greater orientation towards the future. All this could help asylum seekers to experience esteem, consideration, and active participation. Professionals can also use these stories to build processes of investigation, reflection, training, awareness of the institutions that deal with these issues in the community, also to put together more forces to propose significant changes. Therefore, it could be essential to promote the development of scientific and experiential knowledge, i.e., the voice of asylum seekers, among professionals and decision-makers, inviting them to reflect and explore new solutions with a high social value, to the benefit of all (Nota et al., in press).

\section{Conclusion}

Our study has deepened the existing research on asylum seekers and on the challenges, difficulties, and barriers they experienced. We analysed the stories of courage of a group of asylum seekers who found shelter in Italy. The results obtained highlighted dehumanized and undignified human and working conditions that undermined their integrity and physical/psychological wellbeing before, during, and after the migration process. Our study supports the use of narrative procedures in career counseling as a useful tool to support people to develop an orientation towards an inclusive and sustainable future. Through stories of courage counsellors may support asylum seekers in identify their strengths and the social and contextual supports that can help them cope with the transition situation they are experiencing. At the same time asylum seeker stories of courage, expressing the injustice and discrimination that they face such as undignified living conditions, dehumanizing transitions, and barriers imposed on future aspirations, could support carreer counseors in advocacy advertising activities openly challenging the neoliberalism politics of exclusion in favor of more inclusive and sustainable ones.

Funding Open access funding provided by Università degli Studi di Padova within the CRUI-CARE Agreement.

Open Access This article is licensed under a Creative Commons Attribution 4.0 International License, which permits use, sharing, adaptation, distribution and reproduction in any medium or format, as long as you give appropriate credit to the original author(s) and the source, provide a link to the Creative Commons licence, and indicate if changes were made. The images or other third party material in this article are included in the article's Creative Commons licence, unless indicated otherwise in a credit line to the material. If material is not included in the article's Creative Commons licence and your intended use is not permitted by statutory regulation or exceeds the permitted use, you will need to obtain permission directly from the copyright holder. To view a copy of this licence, visit http://creativecommons.org/licen ses/by/4.0/. 


\section{References}

Amnesty International. (2019). La strage silenziosa dei rifugiati nel Mar Mediterraneo: le nostre colpe [The silent massacre of refugees in the Mediterranean Sea: our faults]. Amnesty. https://www.amnes ty.it/giornata-mondiale-rifugiato-strage-mediterraneo/

Andrews, M. (2010). Beyond narrative. In Beyond narrative coherence (pp. 147-166). Amsterdam.

Appels, M., Schons, L. M., \& Korschun, D. (2020). It takes courage! How corporate activism inspires political participation. Academy of Management Proceedings, $2020(1), 14681$.

Aragona, M., Pucci, D., Mazzetti, M., \& Geraci, S. (2012). Post-migration living difficulties as a significant risk factor for PTSD in immigrants: a primary care study. Italian Journal of Public Health. https://doi.org/10.2427/7525

Baudassé, T., Bazillier, R., \& Issifou, I. (2018). Migration and institutions: Exit and voice (from abroad)? Journal of Economic Surveys, 32(3), 727-766. https://doi.org/10.1111/joes.12212

Benezer, G., \& Zetter, R. (2014). Searching for directions: Conceptual and methodological challenges in researching refugee journeys. Journal of Refugee Studies, 28(3), 297-318. https://doi.org/10.1093/ jrs/feu022

Berriane, M., \& De Haas, H. (2012). African migrations research: innovative methods and methodologies. Africa World Press.

Bimrose, J., \& McNair, S. (2011). Career support for migrants: Transformation or adaptation? Journal of Vocational Behavior, 78(3), 325-333. https://doi.org/10.1016/j.jvb.2011.03.012

Bono,A .(2018). Migranti ?! Migranti ?! Migranti ?![Migrants?! Migrants?! Migrants?!]. Segno.

Boyatzis, R. E. (1998). Transforming qualitative information: Thematic analysis and code development. Sage Publications.

Brachet, J. (2016). Policing the desert: The IOM in Libya beyond war and peace. Antipode, 48(2), 272292. https://doi.org/10.1111/anti.12176

Braun, V., \& Clarke, V. (2006). Using thematic analysis in psychology. Qualitative Research in Psychology, 3(2), 77-101. https://doi.org/10.1191/1478088706qp063oa

Chapa, O., \& Stringer, D. (2013). The path of measuring moral courage in the workplace. SAM Advanced Management Journal, 78(2), 17-24. Sage Heart University: https://digitalcommons.sacredheart. edu/conferences/1

Clancy, A., Balteskard, B., Perander, B., \& Mahler, M. (2015). Older persons' narrations on falls and falling-Stories of courage and endurance. International Journal of Qualitative Studies on Health and Well-Being, 10(1), 26123. https://doi.org/10.3402/qhw.v10.26123

Crawley, H., \& Duvell, F. (2017). Unravelling Europe's 'migration crisis': journeys over land and sea. Policy Press.

Crouch, C. (2018). The globalization backlash. Wiley.

Di Maggio, I., Santilli, S., \& Nota, L. (2019). Stories of courage in a group of adults with substance use disorder. Addictive Behaviors Reports. https://doi.org/10.1016/j.abrep.2019.100203

Düvell, F. (2004). Polish undocumented immigrants, regular high-skilled workers and entrepreneurs in the UK. Institute for Social Studies working paper, 54, 1-28. http://pdc.ceu.hu/archive/00001902/ 01/054.pdf

Fereday, J., \& Muir-Cochrane, E. (2006). Demonstrating rigor using thematic analysis: A hybrid approach of inductive and deductive coding and theme development. International Journal of Qualitative Methods, 5(1), 80-92. https://doi.org/10.1177\%2F160940690600500107

Ginevra, M. C., Santilli, S., Nota, L., \& Soresi, S. (2018). Career interventions for career construction and work inclusion of individuals with disability and vulnerability. In T. Hooley, R. Sultana, \& R. Thomsen (Eds.), Career guidance for social justice: Contesting neoliberalism. Routledge.

Guichard, J. (2018). Life design interventions and the issue of work. In V. Cohen-Scali, J. Pouyaud, M. Podgorny, V. Drabik-Podgorna, G. Aisenson, J. L. Bernaud, I. Moumoula, \& J. Guichard (Eds.), Interventions in career design and education Transformation for sustainable development and decent work (pp. 15-28). Springer.

Guichard, J., \& Pouyaud, J. (2018). Life design dialogues for self's construction. In J. A. Athanasou \& H. N. Perera (Eds.), International handbook of career guidance (2nd ed., pp. 15-18). Springer.

Hardoon, D., \& Slater, J. (2015). Inequality and the end of extreme poverty. Oxfam GB. https://policypractice.oxfam.org.uk/publications/inequality-and-the-end-of-extreme-poverty-577506

Hooley, T., Sultana, R., \& Thomsen, R. (Eds.). (2018). Career guidance for emancipation: Reclaiming justice for the multitude (Vol. 18). Routledge. 
Hooley, T., Sultana, R., \& Thomsen, R. (2020). Why a social justice informed approach to career guidance matters in the time of coronavirus. European Commission: https:/epale.ec.europa.eu/en/blog/ why-social-justice-informed-approach-career-guidance-matters-time-coronavirus

Howard, N., \& Forin, R. (2019). Migrant workers, 'modern slavery' and the politics of representation in Italian tomato production. Economy and Society. https://doi.org/10.1080/03085147.2019.1672426

Istat. (2019). Bilancio demografico nazionale. Istat: https://www.istat.it/it/archivio/231884

IX Annual Report of the Directorate General for migration and Integration Policies. (2019). Gli stranieri nel mercato del lavoro in Italia A cura della Direzione Generale dell'Immigrazione e delle Politiche di Integrazione [Foreigners in the labour market in Italy by the Directorate General for migration and Integration Policies]. Ministero del Lavoro e delle Politiche Sociali: https://www.lavoro.gov.it/ documenti-e-norme/studi-e-statistiche/Documents/Nono\%20Rapporto\%20Annuale\%20-\%20Gli\% 20stranieri\%20nel\%20mercato\%20del\%20lavoro\%20in\%20Italia\%202019/Sintesi-IX-Rapporto-itae-ing.pdf

Joseph, G., \& Leach, B. (2016). 8 Neoliberalism, temporary foreign workers and precarious eldercare/ eldercare work. In Joseph (Ed.), Diverse perspectives on aging in a changing world. Routledge.

Koddenbrock, K. (2019). Money and money-ness: Thoughts on the nature and distributional power of the 'backbone' of capitalist political economy. Journal of Cultural Economy, 12(2), 101-118. https:// doi.org/10.1080/17530350.2018.1545684

Marfleet, P. (2006). Refugees in a global era. Palgrave Macmillan.

Markovska, N., Duić, N., Mathiesen, B. V., Guzović, Z., Piacentino, A., Schlör, H., \& Lund, H. (2016). Addressing the main challenges of energy security in the twenty-first century-contributions of the conferences on sustainable development of energy, water and environment systems. Energy, 115, 1504-1512. https://doi.org/10.1016/j.energy.2016.10.086

McMahon, M., Watson, M., \& Bimrose, J. (2012). Career adaptability: A qualitative understanding from the stories of older women. Journal of Vocational Behavior, 80(3), 762-768. https://doi. org/10.1016/j.jvb.2012.01.016

Miller, K., \& Shifflet, R. (2016). How memories of school inform preservice teachers' feared and desired selves as teachers. Teaching and Teacher Education, 53, 20-29. https://doi.org/10.1016/j. tate.2015.10.002

Mulvey, G., \& Davidson, N. (2019). Between the crises: Migration politics and the three periods of neoliberalism. Capital \& Class, 43(2), 271-292. https://doi.org/10.1177/0309816818780652

Nota, L., \& Rossier, J. (Eds.). (2015). Handbook of life design: From practice to theory and from theory to practice. Hogrefe.

Nota, L., \& Soresi, S. (Eds.). (2018). Counseling and coaching in times of crisis and transitions: From research to practice. Routledge.

Nota, L., Soresi, S., Di Maggio, I., Ginevra, M. C., Santilli, S. (in press.) (Eds.). Sustainable development, career counselling and career education. Springer.

O’Neill, M. (2009). Making connections: Ethno-mimesis, migration and diaspora. Journal of Psychoanalysis, Culture and Society, 14, 289-302. https://doi.org/10.1057/pcs.2009.5

O’Neill, M. (2010). Asylum, migration and community. Policy Press.

Obschonka, M., \& Hahn, E. (2018). Personal agency in newly arrived refugees: The role of personality, entrepreneurial cognitions and intentions, and career adaptability. Journal of Vocational Behavior, 105, 173-184. https://doi.org/10.1016/j.jvb.2018.01.003

Ong, A. (2004). Latitudes of citizenship: Membership, meaning, and multiculturalism. In A. Brysk \& G. Shafir (Eds.), People out of place: Globalization, human rights, and the citizenship gap (pp. 53-70). Routledge.

Page, A. (2014). 'How many slaves work for you?' Race, new media, and neoliberal consumer activism. Journal of Consumer Culture, 1(1), 1-16. https://doi.org/10.1177/1469540514553716

Parkins, N. C. (2010). Push and pull factors of migration. American Review of Political Economy, $8(2)$, 6-24. https://sites.bemidjistate.edu/arpejournal/wp-content/uploads/sites/2/2015/11/v8n2parkins.pdf

Peterson, C., \& Seligman, M. E. (2004). Character strengths and virtues: A handbook and classification. Oxford University Press.

Press, R. (2017). Dangerous Crossings: Voices from the African Migration to Italy/Europe. Africa Today, 64(1), 3-27. https://doi.org/10.2979/africatoday.64.1.01

Press, R. M. (2011). Courage, principle and ambition: Human rights activism in Liberia and policy implications for taming authoritarian regimes. Journal of Human Rights Practice, 3(1), 113-127. 
Pury, C. L., Britt, T. W., Zinzow, H. M., \& Raymond, M. A. (2014). Blended courage: Moral and psychological courage elements in mental health treatment seeking by active duty military personnel. The Journal of Positive Psychology, 9(1), 30-41. https://doi.org/10.1080/17439760.2013. 831466

Pury, C. L., Kowalski, R. M., \& Spearman, J. (2007). Distinctions between general and personal courage. The Journal of Positive Psychology, 2(2), 99-114. https://doi.org/10.1080/1743976070 1237962

Pury, C. L., Starkey, C. B., Kulik, R. E., Skjerning, K. L., \& Sullivan, E. A. (2015). Is courage always a virtue? Suicide, killing, and bad courage. The Journal of Positive Psychology, 10(5), 383-388.

Putman, D. A. (2004). Psychological courage. University Press of America.

Putman, D. A. (2010). Philosophical roots of the concept of courage. In C. L. S. Pury \& S. J. Lopez (Eds.), The psychology of courage: Modern research on an ancient virtue (pp. 9-22). American Psychological Association.

Rate, C. R., Clarke, J. A., Lindsay, D. R., \& Sternberg, R. J. (2007). Implicit theories of courage. The Journal of Positive Psychology, 2(2), 80-98. https://doi.org/10.1080/17439760701228755

Riessman, C. K. (2008). Narrative methods for the human sciences. Sage Publications.

Roca-Puig, V. (2019). The circular path of social sustainability: An empirical analysis. Journal of Cleaner Production, 212, 916-924. https://doi.org/10.1016/j.jclepro.2018.12.078

Santilli, S., Di Maggio, I., Ginevra, M. C., Nota, L. (in press.). Stories of courage of young Italians in precarious work. Emerging Adulthood.

Savickas, M. L., Nota, L., Rossier, J., Dauwalder, J.-P., Duarte, E., Guichard, J., Soresi, S., Van Esbroeck, R., \& van Vianen, A. E. M. (2009). Life designing: A paradigm for career construction in the $21 \mathrm{st}$ century. Journal of Vocational Behavior, 75, 239-250. https://doi.org/10.1016/j.jvb.2009.04.004

Schapendonk, J., \& Steel, G. (2014). Following migrant trajectories: The im/mobility of Sub-Saharan Africans en route to the European Union. Annals of the Association of American Geographers, 104(2), 262-270. https://doi.org/10.1080/00045608.2013.862135

Schultheiss, D. E., Watts, J., Sterland, L., \& O’Neill, M. (2011). Career, migration and the life CV: A relational cultural analysis. Journal of Vocational Behavior, 78(3), 334-341. https://doi.org/10. 1016/j.jvb.2011.03.013

Shumam, A., \& Bohmer, C. (2004). Representing trauma: Political asylum narrative. Journal of American Folklore, 117, 394-414.

Tasker, Y. (2002). Soldiers' stories: Women and military masculinities in courage under fire. Quarterly Review of Film and Video, 19(3), 209-222. https://doi.org/10.1080/10509200214842

Thomas, R. J., \& Antony, M. G. (2017). Looking forward. Interdisciplinary perspectives on child migrants: Seen but not heard, 217. Lexington Books.

Toporek, R. L., \& Cohen, R. F. (2017). Strength-based narrative résumé counseling: Constructing positive career identities from difficult employment histories. The Career Development Quarterly, 65(3), 222-236. https://doi.org/10.1002/cdq.12094

UNCHR. (2019). Il numero di persone in fuga nel mondo supera i 70 milioni: l'Alto Commissario delle Nazioni Unite per i Rifugiati chiede maggiore solidarietà [The number of people fleeing the world exceeds 70 million: the United Nations High Commissioner for Refugees calls for greater solidarity]. UNHCR: https://www.unhcr.it/news/numero-persone-fuga-nel-mondo-supera-70-milioni-laltocommissario-delle-nazioni-unite-rifugiati-chiede-maggiore-solidarieta.html

Vogt, G. (2013). When the leading goose gets lost: Japan's demographic change and the non-reform of its migration policy. Journal of Critical Perspectives on Asia, 49(2). https://www.asj.upd.edu.ph/media box/archive/ASJ-49-2-2013/Vogt.pdf

Woodard, C. R. (2004). Hardiness and the concept of courage. Consulting Psychology Journal: Practice and Research, 56(3), 173-185. https://doi.org/10.1037/1065-9293.56.3.173

Publisher's Note Springer Nature remains neutral with regard to jurisdictional claims in published maps and institutional affiliations. 